\title{
Pengaruh Kesehatan Mental, Keaktifan Berorganisasi dan Prestasi AkademikTerhadap Tingkat Pemahaman Moderasi Beragama
}

\author{
Oleh: \\ Herianto, S.Pd.,M.Pd. \\ STKIP YAPTI Jeneponto \\ Email: antoherianto47@gmail.com
}

\section{A. Latar Belakang Masalah}

Indonesia adalah sebuah bangsa dengan komposisi etnis yang sangat beragam. Begitu pula dengan ras, agama, aliran kepercayaan, bahasa, adat istiadat, orientasi kultur kedaerahan, serta pandangan hidupnya. Dengan kata lain, bangsa Indonesia memiliki potensi, watak, karakter, hobi, tingkat pendidikan, warna kulit, status ekonomi, kelas sosial, pangkat dan kedudukan, varian keberagamaan, cita-cita, perspektif, orientasi hidup, loyalitas organisasi, kecenderungan dan afiliasi ideologis yang berbeda-beda ${ }^{1}$.

Indonesia, dengan segala kondisinya yang plural dan banyak perbedaan itu menghadapi ancaman dis-integrasi. Dis-integrasi bangsa Indonesia banyak bersumber dari ideologi-ideologi liberal dan ekstrimis yang masuk dalam ajaran Islam. Ideologi liberal dari barat yang menghendaki adanya kebebasan, yang mengancam moral dan budaya ke-timuran. Akhirnya terwacanakan Islam yang liberal, bebas dan tidak terkontrol. Sisi lain, ekstrimisme merebak di masyarakat Indonesia akibat ajaran Islam transnasional (lintas nasional atau lintas kebangsaan). Ideologi gerakan ini tidak lagi bertumpu pada konsep nation-state, melainkan konsep umat.

Selain maraknya dua pemahaman agama yang ekstrem di atas, belakangan ini muncul beberapa konflik bernuansa keagamaan dan ketegangan dalam masyarakat di Indonesia yang dipicu oleh perbedaan pemahaman atau pandangan keagamaan antar kelompok dalam Islam, seperti dihancurkannya basis Ahmadiyyah dan lain-lain. Konflik itu memang tidakberdiri di

\footnotetext{
${ }^{1}$ Ahmad Syahid,Riuh di Beranda Satu:Peta Kerukunan Umat Beragama di Indonesia, (Jakarta: DEPAG RI, 2003), hlm. 1.
} 
atas perbedaan pandangan keagamaan semata, tetapi akumulasi dari beberap persoalan dan kepentingan, baik politik, ekonomi, sosial, dan lainnya ${ }^{2}$.

Hal serupa juga sudah merambah dalam lembaga pendidikan, khususnya perguruan tinggi Islam.Ada banyak catatan kejadian perilaku yang mengarah kepada radikalisme dan terorisme di lingkungan perguruan tinggi. Misalnya saja pada tanggal 9 Mei 2017, di IAIN Surakarta dihebohkan oleh adanya sikap intoleransi sekelompok orang yang menolak kehadiran Haidar Baqir dalam acara "Bedah Buku Islam Tuhan, Islam Manusia", sehingga kegiatan akademik ini harus dikawal oleh 1.000 personel dari aparat Kepolisian dan $\mathrm{TNI}^{3}$.Kejadian tersebut menjadi saatu contoh dari sekian aksi serupa yang terjadi di perguruan tinggi hingga saat ini.

Berbagai konflik yang terjadi di Indonesia tersebut memang bukan semata-mata karena faktor perbedaan agama. Namun harus diakui bahwa agama seringkali digunakan oleh kelompok yang bertikai sebagai legitimasi bagi tindakannya atau digunakan sebagai pijakan dalam membangun solidaritas kelompoknya dalam berhadapan dengan kelompok lain ${ }^{4}$.

Badan Nasional Penanggulangan Terorisme (BNPT) yang memetakan tingkat radikalisme di Indonesia dalam tiga tingkatan. Pertama, tingkat "waspada" (66,3\%), yaitu pemahaman keagamaan radikal yang dimiliki masyarakat pada umumnya. Kedua, tingkat "bahaya" $(15,4 \%)$, yaitu pemahaman keagamaan radikal yang dimiliki pengurus masjid dan guru sekolah madrasah. Ketiga, tingkat "hati-hati" (20,3\%), yaitu pemahaman keagamaan radikal yang dimiliki mahasiswa. Menurut Mas'ud, salah satu target penyebaran dan perekrutan aksi radikalisme adalah kelompok muda, yang sering disebut sebagai usia "pengantin", yaitu usia antara 18- 31 tahun $^{5}$.Catatan penting dari pemetaan BNPT ini adalah bahwa ternyata tingkat radikalisme di kalangan mahasiswa cukup mengkhawatirkan. Mahasiswa kiranya sangat potensial untuk menjadi target sasaran ideologi keagamaan radikal.

\footnotetext{
${ }^{2}$ Mukhlis M. Hanafi, Moderasi Islam, (Ciputat: Ikatan Alumni Al-Azhar dan Pusat Studi AlQur'an (PSQ), 2013), h. 151

3 Bedah Buku Karya Haidar Bagir di IAIN Surakarta Berlangsung Lancar dalam http://regional.kompas.com/read/2017/05/09/12053501/bedah.buku.di.iain.surakarta.dijaga.1.000.p olisi.dan.tni (diakses pada 15 November 2019).

${ }^{4}$ Afif Rifai, dalam Konflik Etno Religius Indonesia Kontemporer, (Jakarta: DEPAG RI, 2003), h. 20.

${ }^{5}$ BNPT: Hati-Hati Radikalismedi Kalangan Mahasiswa Capai Angka 20,3\%" dalam http://diktis.kemenag.go.id/index.php?berita=detil\&jd=162 (Diakses pada 1 November 2019)
} 
BNPT bahkan meminta civitas akademika mewaspadai gerakan radikalisme di dalam kampus, khususnya mahasiswa baru sebagai entry point. Kalangan yang rentan terpengaruh dan terlibat Gerakan radikalisme adalah anak muda yang banyak ingin tahu namun kondisi dirinya belum stabil ${ }^{6}$.

Dalam perspektif sosiologi sendiri, radikalisme ataupun kejahatan pada umumnya merupakan kondisi alamiah dari masyarakat (crime is a natural part of society) ${ }^{7}$. Dikatakan demikian, karena realitas sosiologi memperlihatkan radikalisme, ditemukan pada hampir semua lapisan dan bentuk masyarakat, apakah masyarakat yang masih sederhana ataupun yang sudah kompleks struktur sosialnya.

Sehingga, radikalisme dibagi menjadi dua tipe atau bentuk. Pertama, radikalisme individual (Individual violence), yaitu radikalisme yang dilakukan oleh seseorang terhadap orang lain. Kedua, radikalisme kelompok (group or collective violence), yaitu bentuk radikalisme yang dilakukan oleh sekelompok orang terhadap seseorang atau kelompok lainnya ${ }^{8}$. Dengan kata lain, pemahaman terhadap moderasi beragama sebagai solusi untuk mencegah tindakan radikalisme negatif, dipengaruhi kondisi internal individu itu sendiri dan faktor dari luar (lingkungan).

Masih banyaknya aksi terorisme dan tindakan yang mengarah kepada radikalisme di Indonesia, khususnya di dunia pendidikan,merupakan bukti konkrit betapa pemahaman dan penghayatan nilai-nilai moderasi Islam masih rendah.Oleh karena itu, berbagai pendekatan penanganan terorisme dan radikalisme harus senantiasa diupayakan. Salah satunya adalah dengan program deradikalisasi melalui pendidikan moderasi Islam.Dalam hal ini, mereka perlu memerhatikan faktor kurikulum, pendidik dan strategi pembelajaran yang digunakan pendidik ${ }^{9}$.

Undang-undang No. Tahun 2003 tentang sistem pendidikan nasional pasal 2 menyebutkan bahwa pendidikan nasional adalah pendidikan yang berdasarkan Pancasila dan

\footnotetext{
${ }^{6}$ Kepala BNPT: Mahasiswa Baru Jadi Incaran Radikalisme dalam https://tekno.tempo.co/read/1241844/kepala-bnpt-mahasiswa-baru-jadiincaran-radikalisme $\quad$ (Diakses 15 November 2019)

${ }^{7}$ J.E. Sahetapy, Kausa Kejahatan dan Beberapa Analisa Kriminologik, (Bandung: Penerbit Alumni, 1981), h. 10.

${ }^{8}$ James M. Henslin, Social Problems, Prentice Hall, Edisi II, (New Jersey: Englewood Cliffs, 1990), h. 154.

9 Andik Wahyun Muqoyyidin, Membangun Kesadaran Inklusif Multikultural untuk Deradikalisasi Pendidikan Islam, Jurnal Pendidikan Islam, (Vol. 2, No. 1 Tahun 2013), hlm. 131.
} 
Undang-Undang Dasar Negara Republik Indonesia Tahun 1945 yang berakar pada nilai-nilai agama, kebudayaan nasional Indonesia dan tanggap terhadap tuntutan perubahan zaman. Pasal ini jelas menandaskan bahwa Pancasila adalah ideologi yang mendasari penyelenggaraan pendidikan di Indonesia, termasuk pendidikan Islam ${ }^{10}$.

Dalam pendidikan, Islam secara tegas memberikan kebebasan sepenuhnya kepada manusia dalam masalah agama dan keberagamaan.AlQur'an juga menganut prinsip adanya realitas tentang pluralitas agama (al-Qur'an 2:62), hidup berdampingan secara damai (alQur'an 109:1-6), tidak ada paksaan dalam beragama, (alQur'an 2:256).Bahkan menganjurkan untuk saling berlomba dalam hal kebajikan (al-Qur'an 5:48) ${ }^{11}$.

Oleh karena itu, peneliti tertarik untuk mengkaji dan membuktikan beberapa permasalahan yang diasumsikan menjadi faktor yang mempengaruhi pemahaman moderasi beragama mahasiswa di perguruan tinggi, khususnya di UIN Alauddin Makassar.Diseminasi hasil penelitian ini akan dipublikasikan pada TARBIYA: Journal Education in Muslim Society Universitas Islam Negeri Syarif Hidayatullah (ISSN: 2442-9848, PISSN : 2442-9848). Selain itu, hasil penelitian dijadikan bahan pengayaan pada mata kuliah Pendidikan Agama Islam dalam bentuk modul atau buku ajar.Hasil penelitian ini juga diharapkan dapat menjadi acuan dan masukan bagi civitas akademika, khususnya di UIN Alauddin Makassar.Dengan mengetahui faktor-faktor yang mempengaruhi moderasi beragama, maka seluruh pihak dapat mengambil langkah tindak lanjut, baik dalam bentuk kebijakan ataupun berupa pengembangan dan penelitian.

\section{B. Permasalahan Penelitian}

Berdasarkan hasil identifikasi permasalahan terkait dengan judul yang telah diangkat, setidaknya ditemukan beberapa permasalahan:

1. Tindakan yang mengarah kepada radikalisme khususnya di dunia pendidikan merupakan bukti konkrit betapa pemahaman dan penghayatan nilai-nilai moderasi Islam masih rendah.

2. Ada indikasi mahasiswa baru di perguruan tinggi rentan tersusupi pemahaman radiakalisme. ayat (2)

${ }^{10}$ Republik Indonesia, Undang-undang No. 20 Tahun 2003 tentang Sistem Pendidikan Nasional, Pasal 1,

${ }^{11}$ Hamdan, Riuh di Beranda Satu: Peta Kerukunan Umat Beragama di Indonesia, (Jakarta: DEPAG RI, 2003), h. 182. 
3. Radikalisme ataupun kejahatan pada umumnya merupakan kondisi alamiah dari masyarakat, karena realitas sosiologi memperlihatkan radikalisme, ditemukan pada hampir semua lapisan dan bentuk masyarakat, apakah masyarakat yang masih sederhana ataupun yang sudah kompleks struktur sosialnya.

4. Pemahaman terhadap moderasi beragama sebagai solusi untuk mencegah tindakan radikalisme negatif dipengaruhi oleh kondisi internal individu itu sendiri dan faktor dari luar (lingkungan). Kondisi internal misalnya kondisi psikologis atau kesehatan mental, kondisi ekonomi, dan sebagainya. Sedangan faktor eksternal atau lingkungan bisa dipengaruhi oleh komunitas, pendidikan, pergaulan, pola asuh dan sebagainya.

\section{Perumusan Permasalahan}

Berdasarkan permasalahan di atas, maka rumusan permasalah dalam penelitian ini yaitu:

1. Adakah pengaruh secara positif dan signifikan kesehatan mental terhadap tingkat pemahaman moderasi beragama mahasiswa program studi PAI Fakultas Tarbiyah dan Keguruan UIN Alauddin Makassar?

2. Adakah pengaruh secara positif dan signifikan keaktifan berorganisasi terhadap tingkat pemahaman moderasi beragama mahasiswa program studi PAI Fakultas Tarbiyah dan Keguruan UIN Alauddin Makassar?

3. Adakah pengaruh secara positif dan signifikan prestasi belajar terhadap tingkat pemahaman moderasi beragama mahasiswa program studi PAI Fakultas Tarbiyah dan Keguruan UIN Alauddin Makassar?

\section{Tujuan Penelitian}

Berdasarkan rumusan masalah di atas, maka tujuan penelitian ini yaitu:

1. Untuk menguji, menganalisis dan mendeskripsikan kesehatan mental berpengaruhsecara positif dan signifikan terhadap tingkat pemahaman moderasi beragama mahasiswa program studi PAI Fakultas Tarbiyah dan Keguruan UIN Alauddin Makassar;

2. Untuk menguji, menganalisis dan mendeskripsikan keaktifan berorganisasi berpengaruh secara positif dan signifikan terhadap tingkat pemahaman moderasi beragama mahasiswa program studi PAI Fakultas Tarbiyah dan Keguruan UIN Alauddin Makassar; 
3. Untuk menguji, menganalisis dan mendeskripsikan prestasi akademik berpengaruh secara positif dan signifikan terhadap tingkat pemahaman moderasi beragama mahasiswa program studi PAI Fakultas Tarbiyah dan Keguruan UIN Alauddin Makassar.

\section{E. Kajian Pustaka}

\section{Kesehatan Mental}

Secara etimologi kata mental berasal dari kata latin, yaitu mens atau mentis yang berarti jiwa, nyawa, sukma, ruh, dan semangat. Kesehatan mental merupakan ahli bahasa dari mental Hygiene atau Mental Health berasal dari kata Hygiene dan Mental. Secara etimologi Hygiene dari kata Hygea yaitu nama dewi kesehatan Yunani kuno yang mempunyai tugas mengurus masalah kesehatan manusia di dunia ${ }^{12}$.

"Kesehatan mental (mental hygeiene) adalah ilmu yang meliputi sistem tentang prinsip-prinsip, peraturan-peraturan serta prosedur-prosedur untuk mempertinggi kesehatan ruhani.Orang yang sehat mentalnya ialah orang yang dalam ruhani atau dalam hatinya selalu merasa tenang, aman, tenteram. Menurut H.C. Witherington, permasalahan kesehatan mental menyangkut pengetahuan serta prinsip-prinsip yang terdapat lapangan psikologi, kedokteran, psikiatri, biologi, sosoilogi,dan agama ${ }^{13}$.

Mental adalah semua unsur-unsur jiwa termasuk pikiran, emosi, sikap (attitude) dan perasaan, pkiran yang dalam keseluruhannya akan menentukan cara laku, cara menghadapi sesuatu hal yang menekan peranan mengecewakan atau menggembirakan, menyenangkan dan sebagainya ${ }^{14}$.

Menurut pandangan Islam, orang yang sehat mentalnya ialah orang yang perilaku, pikiran, dan perasaannya mencerminkan kepribadiannya dan kepribadian tersebut sesuai dengan ajaranIslam.Kondisi seperti ini berarti orang yang sehat mentalnya ialah orang yang didalam dirinyaterdapat keterpaduan antara perilaku, perasaan, pikirannya dan jiwa keberagamannya ${ }^{15}$.

Dari pengertian di atas, dapat diketahui bahwa mental adalah sejumlah unsur jiwa yang memberikan pengaruh terhadap tingkah laku seseorang dalam hidupnya. Seseorang yang

\footnotetext{
${ }^{12}$ Syamsu Yusuf, Mental Hygiene Pengembanagan Kesehatan Mental dalam Kajian Psikologi dan Agama, (Bandung: Pustaka Bani Quraisy, 2004). h. 7.

${ }^{13}$ Jalaluddin.Psikologi Agama, ( Jakarta:PT Raja Grafinda, 2015). h. 156

${ }^{14}$ Zakiah Daradjat, Pendidikan Agama Dalam Pembinaan Mental, (Jakarta: Bulan Bintang, 1982), h. 35.

${ }^{15}$ Zakiah, Daradjat, Kesehatan Mental, Cet. 23, (Jakarta; Toko Gunung Agung, 1996), h. 11.
} 
bermental baik bila unsur-unsur jiwa berjalan penuh keserasian dan terintegrasi, sehingga ia akan mampu menghadapi kesukaran dan goncangan dalam hidupnya dan mampu pula mengadakan penyesuaian diri dengan lingkungannya. Seseorang yang bermental baik atau sehat dapat membawa hidupnya kejenjang kebahagiaan. Sebaliknya seseorang yang tidak baik mentalnya ia akan tenggelam kedalam problema-problema hidup yang membingungkan dan menggoncangkan sehingga dalam perjalanan hidupnya selalu berhadapan pada suasana pertentangan baik dalam dirinya ataupun dengan lingkungannya.

Dengan demikian kesehatan mental adalah jiwa yang terhindar dari gangguan kejiwaan yang dapat membawanya kepada hal-hal yang tidak baik.Adapun mental anak didik adalah kumpulan unsur-unsur psikis dari anak didik seperti emosi, pikiran, sikap dan perasaan yang berpengaruh terhadap tingkah laku dalam suasana di sekolah, rumah tangga dan masyarakat.

Dadang Hawari dalam, al-Qur'an Ilmu Kedokteran dan Kesehatan Jiwa mengemukakan:

Beberapa penyakit mental yang disebabkan oleh seseorang jauh dari al-Qur'an diantaranya adalah sebagai berikut: (1) Riya' yaitu bertingkah laku karena motif ingin dipuji atau diperhatikan orang lain; (2) Hasad dan dengki atau iri hati yaitu tidak suka pada kebahagiaan orang lain; (3) Rakus yaitu hasrat yang berlebih-lebihan dalam makan; (4) Waswas merupakan bisikan hati , akan cita-citadan angan-angannyadalam nafsu dan kelezatan; (5) Bicara berlebih-lebihan yang akan menimbulkan kebohongan; (6) Menyumpahi atau mendoakan hal-hal yang buruk terhadap orang lain; (7) Ingkarjanji; (8) Mengadukan orang lain (namimah) yaitu menyampaikan hal-hal yang tidak disukai oleh orang yang bersangkutan; (9) Membicarakan kejelekan orang lain di belakang orang tersebut (ghibah); (10) Sangat marah (syiddat al-ghadap); (11) Cinta dunia (hubb ad dunya); (12) Cinta harta (hub al-Mal); (13) Kebakhilan yaitu pelit atau menyembunyikan dan menumpuk harta; (14) Cinta pada kedudukan atau pangkat (hubb al-Jah); (15) Kesombongan (kibr) atau bangga (ujub) ${ }^{16}$

Sedangkan indikator kesehatan mental menurut WHO dalam Sururin (2004) yaitu sebagai berikut:

1) Bebas dari ketegangan dan kecemasan;

2) Menerima kekecewaan sebagai pelajaran di kemudian hari;

3) Dapat menyesuaikan diri secara konstruktif pada kenyataan meskipun kenyataan itu pahit;

4) Dapat berhubungan dengan orang lain dan dapat tolong menolong yang memuaskan;

${ }^{16}$ Dadang Hawari, Al-Qur'an Ilmu Kedokteran dan Kesehatan Jiwa, (Yogyakarta : Dana Bkahti Prima Yasa, 1996), h. 112. 
5) Merasa lebih puas memberi dari pada menerima;

6) Dapat merasakan kepuasan dari perjuangan hidupnya;

7) Dapat mengarahkan rasa permusuhan pada penyelesaian yang kreaktif dan konstruktif;

8) Mempunyai rasa kasih sayang dan butuh disayangi;

9) Mempunyai spritual atau agama. ${ }^{17}$

\section{Keaktifan Berorganisasi}

Organisasi kemahasiswaan kampus merupakan suatu wadah atau organisasi yang bergerak di bidang kemahasiswaan, yang di dalamnya dilengkapi dengan perangkat teknis yang jelas dan terencana seperti struktur, mekanisme, fungsi, prosedur, program kerja, dan elemen lainnya yang berfungsi mengarahkan seluruh potensi yang ada dalam organisasi tersebut pada tujuan atau cita-cita akhir yang ingin dicapainya ${ }^{18}$.

Organisasi kemahasiswaan pada dasarnya diharapkan mampu membentuk mahasiswa yang jauh melampaui kecakapan teknis dalam penyelenggaraan kegiatan.Kecakapan yang dapat dikembangkan dalam organisasi kemahasiswaan, misalnya meningkatkan kemampuan berpikir kritis, kedewasaan dan kematangan dalam bersikap, meningkatkan kreativitas dan yang tak kalah penting adalah meningkatkan prestasi berdasarkan backgraund organisasi kemahasiswaan tersebut ${ }^{19}$.

Terkhusus organisasi kemahasiswaan intra kampus, UIN Alauddin Makassar berpedoman pada Keputusan Direktur Jenderal Pendidikan Islam Departemen Agama R.I. Nomor: 1741 Tahun 2013 tentang Pedoman Umum Organisasi Kemahasiswaan PTAI dan Keputusan Rektor UIN Alauddin Makassar Nomor: 174 Tahun 2017 tentang Pedoman Dasar Organisasi Kemahasiswaan UIN Alauddin Makassar. Berdasarkan peraturan tersebut, organisasi kemahasiswaan yang ada di Universitas Islam Negeri (UIN)Alauddin dapat dikelompokkan menjadi beberapa bentuk, yaitu: Dewan Mahasiswa (DEMA) tingkat Universitas dan Fakultas, Senat Mahasiswa (SEMA) tingkat Universitas dan Fakultas,

\footnotetext{
${ }^{17}$ Sururin, Ilmu Jiwa Agama, (Jakarta:PT Raja Grafindo Persada, 2004), h. 146.

${ }^{18}$ Launa, Gerakan Intelektual Dan Aksi Massa Mahasiswa: Refleksidan Prospeksi Peran Politik Mahasiswa Era Orde Baru, Jurnal Widya, Edisi 183, Tahun 2000, h. 32.

19 Suroto, Dinamika Kegiatan Organisasi Kemahasiswaan Berbasis Kearifan Lokal Dalam Upaya Memperkuat Karakter Unggul Generasi Muda, Jurnal Pendidikan Kewarganegaraan,Vol. 6, No.2, (Banjarmasin: Universitas Lambung Mangkurat, 2016), h. 1042.
} 
Himpunan Mahasiswa Jurusan (HMJ), dan Unit Kegiatan Mahasiswa (UKM). Terkhusus di Fakultas Tarbiyah, Dewan Mahasiswa (DEMA) menaungi 3 lembaga kemahasiswaan yaitu Lembaga Pers Otodidak, Lembaga Seni Estetika dan Lembaga Olahraga.

Sedangkan untuk organisasi kemahasiswaan ektra kampus, terdapat beragam organisasi kemahasiswaan mainstream tercatat aktif di lingkungan UIN Alauddin Makassar, seperti: Himpunan Mahasiswa Islam (HMI), Pergerakan Mahasiswa Islam Indonesia (PMII), Ikatan Mahasiswa Muhammadiyah (IMM), Kesatuan Aksi Mahasiswa Muslim Indonesia (KAMMI), dan organisasi kajian dan pergerakan mahasiswa lainnya. Selain itu, terdapat pula berbagai organisasi kemahasiswaan yang berbentuk organisasi kepemudaan dan kemasyarakatan, kelompok studi, lembaga swadaya, lembaga kekaryaan dan asosiasi lainnya.

Ratminto dan Atik menyebutkan bahwa untuk mengukur aktif atau tidaknya seseorang dalam berorganisasi, dibutuhkan beberapa ukuran. Ukuran aktif berorganisasi adalah sebagai berikut:

1) Responsivitas, yaitu kemampuan menyusun agenda dan prioritas kegiatan.

2) Akuntabilitas, yaitu ukuran yang menunjukkan tingkat kesesuaian kinerja dengan ukuran eksternal, seperti nilai dan norma dalam masyarakat.

3) Keadaptasian, yaitu mampu atau tidaknya beradaptasi dengan lingkungan sekitar.

4) Empati, yaitu kepekaan terhadap isu-isu yang sedang berkembangdi lingkungan sekitar.

5) Keterbukaan atau transparasi, yaitu mampu atau tidaknyaseseorang bersikap terbuka dengan sekitar ${ }^{20}$.

Menurut Priambodo dan Sarwono, terdapat beberapa ciri yang melekat dalam diri mahasiswa yang aktif dalam organisasi kemahasiswaan.

1) Senang menghabiskan waktu dengan berbagai kegiatan kemahasiswaan. Mahasiswa yang aktif dalam organisasi kemahasiswaan hampir selalu ingin terlibat dalam kepengurusan harian maupun kepanitiaan berbagai kegiatan dan acara yang diadakan organisasinya. Merekan bersedia untuk terlibat aktif mendorong pelaksanaan berbagai kegiatan dalam organisasi tempatnya bergabung.

2) Cenderung sering duduk-duduk dan berbincang-bincang di ruangan atau kantor organisasi kemahasiswaan yang diikuti. Mahasiswa-mahasiswa yang aktif dalam

\footnotetext{
${ }^{20}$ Atik Septi Winarsih dan Ratminto,Manajemen Pelayanan, (Yogyakarta: Pustaka Pelajar, 2012), h. 181-
} 182. 
organisasi kemahasiswaan cendrung lebih banyak meluangkan waktunya untuk berkumpul di ruangan atau kantor organisai sambil duduk-duduk dan berbincangbinsang dengan sesame anggota organisasi lainnya mengenai hal-hal yang berkaitan dengan organisasi yang diikuti maupun mengenai isu-isu yang beredar di lingkungan luar atau masyarakat

3) Cenderung mempunyai wawasan yang luas tentang perkembangan dunia luar maupun tentang hal-hal yang terjadi di seputar kampus. Disamping memiliki wawasan yang luas, mahasiswa yang aktif dalam organisasi kemahasiswaan juga cendrung memandang segala sesuatu secara kritis. Mereka cederung lebih peka dan lebih kritis terhadap perkembangan kejadian-kejadian di lingkungan liat, mosalnua perkembangan keadaan politik di dalam maupun luar negeri ${ }^{21}$.

\section{Prestasi Akademik}

Prestasi adalah hasil yang telah dicapai, dilakukan dan dikerjakan oleh seseorang $^{22}$.Prestasi sendiri terbagi dua, yakni prestasi akademik dan non akademik.Prestasi akademik menurut Bloom merupakan hasil perubahan perilaku yang meliputi ranah kognitif, ranah afektif, dan ranah psikomotor yang merupakan ukuran keberhasilan peserta didik ${ }^{23}$.

Ranah kognitif dalam hal ini merupakan kemampuan yang selalu dituntut kepada anak didik untuk dikuasai karena kemampuan di ranah ini menjadi dasar bagi penguasaan ilmu pengetahuan $^{24}$.

Prestasi akademik dinyatakan sebagai pengetahuan yang dicapai atau keterampilan yang dikembangkan dalam mata pelajaran atau mata kuliah tertentu di lembaga pendidikan, biasanya ditetapkan dengan nilai akademik ${ }^{25}$.Sehingga dapat disimpulkan bahwa prestasi akademik adalah hasil belajar mahasiswa dari serangkaian pembelajaran yang dituangkan dalam sebuah nilai akademik.

${ }^{21}$ Leny dan P. Tommy Y. Suyasa, Keaktifan Berorganisasi dan Kompetensi Interpersonal, Jurnal Phronesis Juni 2006, Vol. 8, No1, (Bandung: Unikversitas Tarumanegara, 2006), h. 83.

${ }^{22}$ Baiti, H. N, Pengaruh Rasa Percaya Diri Terhadap Prestasi Belajar Siswa Kelas VIII Di MTs Miftahul Huda Muncar Banyuwangi 2009-2010, (Malang: Fakultas Psikologi, 2010), h. 43. 22-23.

${ }^{23}$ Nana Sudjana, Penilaian Hasil Proses Belajar Mengajar, (Bandung : PT. Remaja Rosdakarya), 2009), h.

${ }_{24}^{24}$ Slameto, Belajar dan Faktor-faktor yang Mempengaruhinya, (Jakarta: Rineka Cipta, 2003) h. 4.

${ }^{25}$ Sumadi Suryabrata, 2014, Psikologi Pendidikan, (Jakarta: Rajagrafindo Persada), h. 12. 
Untuk kebutuhan penelitian, maka nilai prestasi akademik yang dimaksudkan adalah akumulasi nilai hasil belajar mahasiswa Fakultas Tarbiyah dan Keguruan dari keseluruhan mata kuliah yang telah diprogramkan.Nilai prestasi akademik tersebut dituangkan dalam Indeks Prestasi Kumulatif (IPK) sementara.

\section{Pemahaman Moderasi Beragama}

Moderasi Islam dalam bahasa arab disebut dengan al-Wasathiyyah al-Islamiyyah. AlQaradawi menyebut beberapa kosakata yang serupa makna dengannya termasuk katan Tawazun, I'tidal, Ta'adul dan Istiqamah. Sementara dalam bahasa inggris sebagai Islamic Moderation $^{26}$.Sedangkan menurut Kamus Besar Bahasa Indonesia, Moderasi berarti kecenderungan berada dititik tengah di antara dua buah kutub ekstrim ${ }^{27}$.

ModerasiIslam adalah sebuah pandangan atau sikap yang selalu berusaha mengambil posisi tengah dari dua sikap yang berseberangan dan berlebihan sehingga salah satu dari kedua sikap yang dimaksud tidak mendominasi dalam pikiran dan sikap seseorang. Dengan kata lain seorang muslim moderat adalah muslim yang memberi setiap nilai atau aspek yang berseberangan bagian tertentu tidak lebih dari porsi yang semestinya. Karena manusia-siapa pun ia- tidak mampu melepaskan dirinya dari pengaruhdan bias baik pengaruh tradisi, pikiran, keluarga, zaman dan tempatnya, maka ia tidak mungkinmerepresentasikan atau mempersembahkan moderasi penuh dalam dunia nyata. Hanya Allah yang mampu melakukan hal itu ${ }^{28}$.

Menurut Hashim Kamali, moderasi merupakan aspek penting dalam Islam, dimana moderasi dalam Islam mengandung banyak ramifikasi dalam berbagai bidang yang menjadi perhatian Islam.Kamali mengungkapkan bahwa moderasi menyangkut kebajikan moral yang relevan, tidakhanya dengan kehidupan individual, tetapi juga integritas dan citra diri komunitas danbangsa ${ }^{29}$.

Moderasi juga kebajikan yang membantu terciptanya harmoni sosial, dan keseimbangan dalam kehidupan dan masalah individual, baik dalam keluarga maupun masyarakat, serta spektrum hubungan antar manusia yang lebih luas.

\footnotetext{
${ }^{26}$ Yusuf Al-Qaradawi, Sistem Pengetahuan Islam, (Jakarta: Restu Ilahi, 2004), h. 13.

${ }^{27}$ Kementerian Pendidikan dan Kebudayaan RI, Kamus Besar Bahasa Indonesia Pusat Bahasa.(Jakarta: PT Gramedia Pustaka Utama, 2014), h. 50.

${ }^{28}$ Yusuf Al-Qaradawi, Sistem Pengetahuan Islam, h. 13.

${ }^{29}$ Mohammad Hashim Kamali, The Middle Pathof Moderationin Islam-The Qur'anic Principle of Wasatiyyah, Edisi I, (London: Oxford University Press, 2015), h. 15.
} 
Istilah moderasi, dan lawan katanya ekstremisme dan radikalisme, sejak beberapa tahun terakhir menjadi sangat populer.Karena begitu pepulernya di hampir semua pidato pemimpin negara, termasuk pidato Raja Salman di gedung MPR RI, juga mengulangi katakata itu berkali-kali. Tidak luput tentunya hampir di semua pidato kampanye maupun debat capres AS ketika itu selalu menyebut-nyebut kata moderasi dan lawan katanya ekstremisme atau radikalisme ${ }^{30}$.

Adapun indikator yang dikembang untuk menilai tingkat pemahaman mahasiswa dalam penelitian ini sesuai dengan pengertian yang dkijelkaskan oleh Kementerian Agama Republik Indonesia, yaitu: 1) komitmen kebangsaan; 2) toleransi; 3) anti-kekerasan; dan 4) akomodatif terhadap kebudayaan lokal. Keempat indikator ini dapat digunakan untuk mengenali seberapa kuat moderasi beragama yang dipraktikkan oleh seseorang di Indonesia, dan seberapa besar kerentanan yang dimiliki.Kerentanan tersebut perlu dikenali supaya kita bisa menemukenali dan mengambil langkah-langkah yang tepat untuk melakukan penguatan moderasi beragama ${ }^{31}$.

\section{F. Landasan Teori dan Kerangka Konseptual}

Beberapa hasil penelitian terdahulu mengenai kesehatan mental, keaktifan berorganisasi dan prestasi akademik beserta pengaruhnya terhadap tingkat pemahaman moderasi beragama dijadikan peneliti sebagai acuan dalam penelitian ini, diantaranya:

1. Tim Penyusun Kementerian Agama RI (2019), menjelaskan bahwa moderasi beragama meniscayakan umat beragama untuk tidak mengurung diri, tidak eksklusif (tertutup), melainkan inklusif (terbuka), melebur, beradaptasi, bergaul dengan berbagai komunitas, serta selalu belajar di samping memberi pelajaran ${ }^{32}$. Penjelasan tersebut memberikan gambaran bahwa ada faktor internal (psikologis) dan faktor eksternal (komunitas/organisasi) dari tiap individu atau warga negara (khususnya mahasiswa)dalam memahami dan menerapkan moderasi beragama sebagai sebuah nilai dalam kehidupan berbangsa dan bernegara.

\footnotetext{
${ }^{30}$ Rt. Bai Rohimah, Persepsi Santri tentang Moderasi Islam dan Wawasan Kebangsaan, Jurnal Hayula, Vol. 3, No. 2, Juli 2019, (Serang: FKIP UNTISTA, 2019) h. 141-142).

${ }^{31}$ Tim Penyusun Kementerian Agama RI, Moderasi Beragama, Cet. I, (Jakarta: Kementerian Agama RI, 2019), h. 43.

${ }^{32}$ Tim Penyusun Kementerian Agama RI, Moderasi Beragama, h. 22.
} 
2. Studi dari Rahmayulius (2002) mengungkap bahwa sejumlah kasus yang menunjukan adanya hubungan antara faktor keyakinan (agama) dengan kesehatan jiwa atau mental tampak nya sudah disadari para ilmuan beberapa abad yang lalu. Kenyataanserupa itu juga akan dijumpai dalam banyak buku yang mengungkapkan betapa eratnya hubungan antara agama dan kesehatan mental. Hubungan antara kejiwaan dan agama dalam kaitannya dengan hubungan antara agama sebagai keyakinandan kesehatan jiwa, terletak pada sikap penyerahan diri seseorang terhadap suatu kekuasaan yang maha tinggi (Allah SWT $)^{33}$.

3. Ahmad Nurrohim (2016) mengungkapkan bahwa kualitas karakter atau perilaku positif seseorang dapat diupayakan dengan penyehatan jiwa (tazkiyah nafs), yang dapat dicapai melalui berbagai metode, media dan alat ukur temuan sarjana muslim dan non-muslim, dengan dengan tetap mengacu pada indikator kesehatan jiwa dan tujuan tazkiyah nafs ${ }^{34}$. Sebagai sebuah sikap, moderasi beragama dalam penelitian di atas memiliki kaitan yang dengan kualitas mental.

Berdasarkan landasan pemikiran dan penelitian terdahulu di atas, maka peneliti menilai relevan untuk menguji, menganalisis dan mendiskripsikan tingkat kesehatan mental, keaktifan berorganisasi dan prestasi akademik sebagai variabel bebas (Independent Variable) terhadap tingkat pemahaman moderasi beragama mahasiswa sebagai variabel terikat (Dependent Variable). Adapun kerangka konseptual dalam penelitian ini digambarkan dalam bagan alir 1.1 berikut:

\footnotetext{
${ }^{33}$ Ramayulis, Psikologi Agama, (Jakarta: Kalam Mulia, 2002 ), h. 133-134.

${ }^{34}$ Ahmad Nurrohim, Mental Dan Pendidikan Karakter: Pandangan Keislaman Terintegrasi, Jurnal Attarbiyah, Vol. I, No. 2, (Salatiga: IAIN Salatiga, 2016), h.273-302.
} 


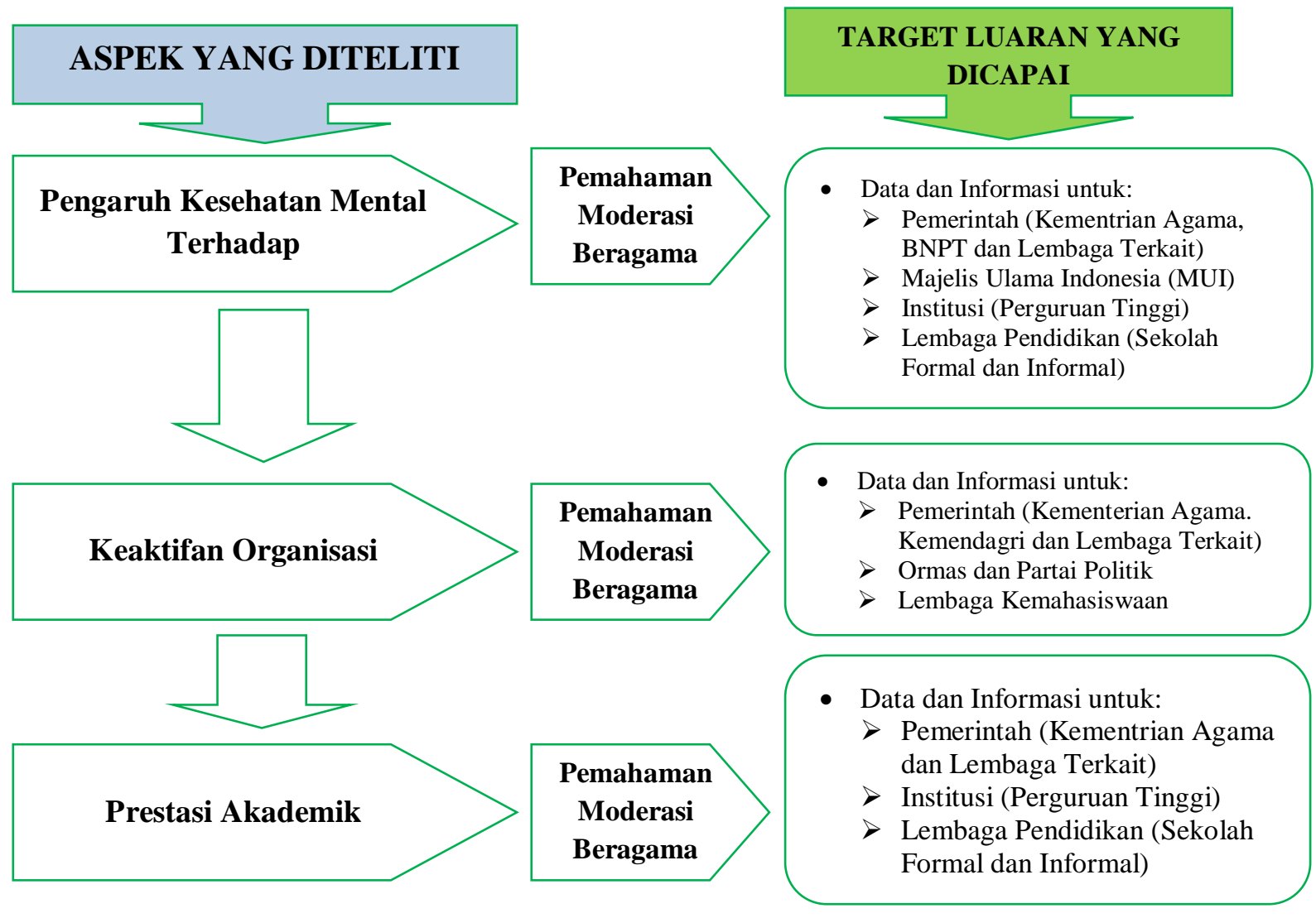

Hasil Penelitian Kompetitif - Puslitbangda Pengda, diharapkan menjadi sumber acuan: (Peraturan Pemerintah, Peraturan Menteri, Peraturan Daerah, Peraturan Akademik, Bahan Ajar, Aturan Kelembagaan Organisasi Kemahasiswaan. Ormas. dan Parbol)

Seminasi Hasil Penelitian:
(Publikasi Buku Teks/Ajar ber-ISBN \& Jurnal Internasional, Hak Atas Kekayaan Intelektual (HKI) - Hak
Paten, MoU dengan Institusi Perguruan Tinggi dalam Bentuk Kurikulum Perguruan Tinggi)

Bagan Alir 1.1 Kerangka Konseptual Penelitian

\section{G. Hipotesis}

Berdasarkan landasan teori dan kerangka konseptual di atas, penelitian ini disusun dengan hipotesis sebagai berikut:

$\mathrm{H}_{0}=\mu>0,05$ : Tidak ada pengaruh secara signifikan antara kesehatan mental, keaktifan berorganisasi dan prestasi akademik terhadap tingkat pemaham moderasi beragama; 
$\mathrm{H}_{1}: \mu \leq 0,05$ : Ada pengaruh secara signifikan antara kesehatan mental, keaktifan berorganisasi dan prestasi akademik terhadap tingkat pemaham moderasi beragama.

\section{H. Metodologi Penelitian}

\section{Jenis Penelitian}

Jenis penelitian yang digunakan adalah penelitian kuantitatif ${ }^{35}$ dengan desain penelitian studi pengujian hipotesis (hypothesis testing study) yang bertujuan untuk menganalisis, mendeskripsikan, dan mendapatkan bukti empiris pola hubungan antara dua variabel atau lebih, baik yang bersifat korelasional (correlation), kausalitas (causality) maupun yang bersifat komparatif (comparative) ${ }^{36}$.

Penelitian ini bertujuan untuk mencari pengaruh langsung antara variabel bebas (independent variable) dengan variabel terikat (dependent variabel) dan juga mencari pengaruh secara tidak langsung antara variabel bebas (independent variable) dengan variabel terikat (dependent variabel).Metode ini disebut sebagai metode kuantitatif karena data penelitian berupa angka dan analisis menggunakan statistik.

\section{Populasi dan Sample}

Populasi dalam penelitian ini adalah seluruh mahasiswa semester 6 (enam) program studi PAI tahun ajaran 2019/ 2020 yang berjumlah 108 orang. Teknik pengambilan sampel menggunakan probability sampling dengan tekniksimple random sampling. Rumus yang digunakan adalah rumus Slovin dengan toleransi kesalahan 5\% sehinggadihasilkan sampel sebanyak 86 orang.

\section{Metode Pengumpulan Data}

Data penelitian diambil dari data primer yang diambil dari mahasiswa semester 6 (enam) program studi PAI Fakultas Tarbiyah dan Keguruan UIN Alauddin Makassar. Mahasiswa semester 6 (enam) diasumsikan masih aktif dalam proses perkuliahan di program studi PAI, melewati proses kepengurusan di organisasi kampus, dan tidak sedang disibukkan oleh urusan penyelesaian studi.

\footnotetext{
35 Jusmiana, A. (2020). Sekapur Sirih Tentang Statistik.

${ }^{36}$ Wahyudin, Agus, Metodologi Penelitian Bisnis Dan Manajemen, (Semarang: Fakultas Ekonomi Universitas Negeri Semarang, 2015), h. 15.
} 
Metode pengumpulan data yang digunakan untuk variabel kesehatan mental yaitu dengan menggunakan tes kesehatan mental yang divalidasi dari instansi resmi/rumah sakit/psikolog yang kredibel. Sedangkan variabel prestasi belajar diambil dari dokumentasi hasil belajar mahasiswa.Adapun variabel keaktifan berorganisasi dan tingkat pemahaman moderasi beragama adalah metode angket. Adapun angket yang digunakan adalah angket tertutup yang telah disediakan jawabannya.

Tabel 1.1

Metode Pengumpulan Data

\begin{tabular}{|c|c|c|}
\hline Variabel & Cara Pengujian & Alat Pengujian \\
\hline Kesehatan mental & $\begin{array}{c}\text { Instansi resmi/rumah } \\
\text { sakit/psikolog yang kredibel }\end{array}$ & Tes kesehatan mental \\
\hline Prestasi belajar & $\begin{array}{c}\text { Dokumentasi hasil belajar } \\
\text { mahasiswa }\end{array}$ & Prestasi Akademik \\
\hline Keaktifan berorganisasi & $\begin{array}{c}\text { Tingkat Keaktifan } \\
\text { berorganisasi }\end{array}$ & $\begin{array}{c}\text { Jumlah Organisasi dan } \\
\text { Jabatan dalam Organisasi }\end{array}$ \\
\hline Moderasi beragama & Tingkat pemahaman & Metode angket \\
\hline
\end{tabular}

\section{Instrumen Penelitian}

Instrumen utama dalam penelitian ini adalah peneliti sendiri. Kedudukan peneliti dalam penelitian kualitatif berperan sebagai instrumen kunci (key instrument). Peneliti sebagai perencana, pelaksana pengumpulan data, analisis, dan pelapor hasil penelitian. Oleh karena itu, kehadiran peneliti secara langsung di lapangan secara langsung dan aktif dengan informan mutlak diperlukan Peneliti mempergunakan berbagai bentuk alat bantu untuk menunjang keabsahan penelitian, namun berfungsi sebagai pendukung yakni pedoman wawancara, pedoman observasi, dan tape recorder.

\section{Metode Analisis Data}

\section{a. Analisis Deskriptif}

Analisis deskriptif hasil penelitian ini dihitung dengan mencari besaran interval dengan skala likert, sehingga didapatkan predikat dari variabel kesehatan mental, keatifan berorganisasi, prestasi belajar dan tingkat pemahaman moderasi keagamaan.Data yang terkumpul dituliskan dalam tabulasi data.

Hasil tabulasi data dari masing-masing variabel kemudian dianalisis dengan menggunakan software program SPSS (Statistical Package and Social Science) versi 22.Data 
deskripstif tersebut diantaranyanilai rata-rata dan standar deviasi dari masing-masing variabel yang diteliti, baik variabel independen maupun variabel dependen.

\section{b. Analisis Inferensial}

Analisis inferensial merupakan analisis yang digunakan untuk pengujian hipotesis variabel yaitu uji pengaruh langsung dengan menggunakan alat analisis berupa software program SPSS (Statistical Package and Social Science) versi 22.Sebelum melakukan pengujian hipotesis tersebut, terlebih dahulu dilakukan uji prasyarat analisis atau uji asumsi klasik yang meliputi uji normalitas dan uji linearitas, serta uji asumsi klasik yang meliputi uji multikolonieritas dan uji heteroskedastisitas.

1) Uji Asumsi Klasik

a) Uji Normalitas

Uji normalitas dilakukan menggunakan nilai Kolmogorov-smirnov menggunakan SPSS versi 22 dan diperoleh nilai signifikan dengan variabel tingkat pemahaman moderasi beragama mahasiswa sebagai variabel dependen. Penarikan kesimpulan dari uji normalitas ini yaitu jika nilai di atas 0,05 maka dapat dikatakan bahwa data residual dengan tingkat pemahaman moderasi beragama sebagai variabel dependen berdisribusi normal.

b) Uji Linearitas

Uji linearitas yang digunakan adalah Uji Lagrage Multiplier.Pada pengujian ini, nilai c2 hitung akandibandingkan dengan c2 tabel dengan tingkat signifikansi sebesar 0,05. Jika c2 hitung < c2 tabel maka dapat disimpulkan bahwa bentuk persamaan dari penelitian ini memiliki hubungan linear.

c) Uji Multikolonearitas

Uji multikolinieritas adalah untuk melihat ada atau tidaknya korelasi yang tinggi antara variabel-variabel bebasnya, maka hubungan antara variabel bebas terhadap variabel terikatnya menjadi terganggu. Semakin besar korelasi diantara sesama variabel independen maka tingkat kesalahan dari koefisien regresi semakin besar yang dapat mengakibatkan standar error semakin besar pula. Cara yang digunakan untuk mendeteksi ada tidaknya multikolinieritas adalah dengan melihat besarnya nilai variance inflation factor (VIF). Jika IF dibawah 10 dan Tolerance Value diatas 0,1 maka tidak terjadi multikolinieritas. 


\section{2) AnalisisRegresi Berganda}

Menurut Danang Sunyoto, tujuan dari analisis regresi adalah untuk mengetahui besarnya pengaruh variabel bebas $(\mathrm{X})$ terhadap variabel terikat $(\mathrm{Y})^{37}$. Penelitian ini menggunakan analisis regresi berganda karena pengukuran pengaruh antarvariabel melibatkan lebih dari satu variabel bebas (X1, X2, . . Xn).Analisis regresi berganda bermaksud meramalkan bagaimana naik turunnya variabel dependen, bila dua atau lebih variabel independen sebagai faktor prediktor dimanipulasi atau dinaikturunkan nilainya.Adapun bentuk umum dari persamaan regresi linier berganda secara sistematis menurut Sugiyono ${ }^{38}$ adalah sebagai berikut:

$$
Y=a+b_{1} X_{1}+b_{2} X_{2}+b_{3} X_{3}+e
$$

Keterangan:

$\mathrm{Y}=$ Tingkat Pemahaman Mokderasi Beragama;

$\mathrm{X}_{1}=$ Aspek Kesehatan Mental;

$\mathrm{a}=$ Konstanta

$\mathrm{X}_{2}=$ Aspek Keaktifan Berorganisasi;

$\mathrm{b}_{1}=$ Koefisien regresi $\mathrm{X}_{1}$;

$\mathrm{b}_{2}=$ Koefisien regresi $\mathrm{X}_{2}$;

$\mathrm{X}_{3}=$ Aspek Prestasi Akademik;

$\mathrm{b}_{3}=$ Koefisien regresi $\mathrm{X}_{3}$; e $=$ Std. Error.

\section{3) PengujianHipotesis}

Hipotesis adalah asumsi atau dugaan mengenai suatu hal yang dibuat untuk menjelaskan suatu hal yang sering dituntut untuk melakukan pengecekannya.Uji signifikansi pengaruh variabel independen terhadap variabel dependen secara simultan menggunakan uji $F$ dan secara parsial menggunakan uji t.

\section{a) Pengujian Secara Parsial (Uji $t$ )}

Uji t atau uji koefisien regresi secara parsial digunakan untuk mengetahui apakah secara parsial variabel independen berpengaruhsecara signifikan atau tidaknya terhadap variabel dependen ${ }^{39}$.Uji t dilakukan dengan mencari t hitung 2 pihak dengan tingkat signifikan

\footnotetext{
${ }^{37}$ Danang Sunyoto, Teori, Kuesioner, dan Analisis Data Sumber Daya Manusia dalam Organisasi Sekolah, (Yogyakarta: Multi Presindo, 2013), h. 47.

${ }^{38}$ Sugiyono, Metode Penelitian Kuantitatif Kualitatif dan R\&D, (Bandung: Alfabeta, 2012), h.277.

${ }^{39}$ Duwi Priyatno, Cara Kilat Belajar Analisis Data dengan SPSS 20, (Yogyakarta: Andi Offset, 2012), h.139.
} 
sebesar $a=0,05$. Analisis dilakukan menggunakan program SPSS dengan menggunakan rumus sebagai berikut:

$$
t=\frac{r \sqrt{n-2}}{1-r^{2}}
$$

Keterangan:

$t=$ nilai uji $\mathrm{t}$

$r=$ nilai koefisien korelasi

$n=$ jumlah sampel yang diobservasi

Penarikan kesimpulan dilakukan dengan ketentuan sebagai berikut:

- Ho diterima jika nilai hitung statistik uji t berada di daerah penerimaan, dimana $t$ hitung - t tabel< - thitung dan $t$ hitung $<$ t table;

- Ho ditolak jika nilai hitung statistik uji t berada di daerah penolakan $H o$, dimana $t$ hitung $>t$ tabel dan - t hitung $<-t$ tabel.

b) Pengujian Secara Simultan (Uji Statistik $F$ )

Uji $\mathrm{F}$ atau uji koefisien regresi secara bersama-sama digunakan untuk mengetahui apakah secara bersama-sama variabel independen berpengaruh signifikan terhadap variabel dependen $^{40}$. Pengujian simultan dilakukan dengan menentukan $F$ hitung dengantingkat signifikan sebesara $=0,05$. Analisis dilakukan menggunakan program SPSS dengan menggunakan rumus sebagai berikut:

$$
F=\frac{R /(K-1)}{\left(1-R^{2}\right)(N-K)}
$$

Keterangan: $\quad r=$ Nilai koefisien korelasi parsial $; k=$ Jumlah variabel bebas

$n=$ Jumlah sampel;

Penentuan penerimaan dan penolakan dugaan atas hipotesis yang diajukan yaitu:

- Ho ditolak jika $F$ hitung $>F$ tabel

- Ho diterima jika $F$ hitung $<F$ tabel

Atau pengambilan keputusan berdasarkan signifikansi:

- $\quad F$ sig<a, maka Ho ditolak, berarti variabel independen secara simultan berpengaruh terhadap variabel dependen.

\footnotetext{
${ }^{40}$ Duwi Priyatno, Cara Kilat Belajar Analisis Data dengan SPSS 20, h.137.
} 
- F sig $>a$, maka $H o$ diterima, berarti variabel independen secara simultan tidak mempengaruhi variabel dependen.

c) Pengujian Determinasi

Analisis koefisien determinasi $(\mathrm{Kd})$ digunakan untuk melihat seberapa besar variabel independen (X) berpengaruh terhadap variabel dependen (Y) yang dinyatakan dalam persentase. Besarnya koefisien determinasi dihitung dengan menggunakan rumus sebagai berikut:

$$
K d=r^{2} x 100 \%
$$

Keterangan: $\quad d=$ Koefisien determinasi

$r=$ Koefesien korelasi

\section{Daftar Pustaka}

Al-Qaradawi, Yusuf. 2004. Sistem Pengetahuan Islam. Jakarta: Restu Ilahi.

Baiti, H. N. 2010. Pengaruh Rasa Percaya Diri Terhadap Prestasi Belajar Siswa Kelas VIII Di MTs MiftahulHuda Muncar Banyuwangi 2009-2010. Malang: Fakultas Psikologi.

Daradjat, Zakiah. 1996.Kesehatan Mental. Cet. XXIII. Jakarta: Toko Gunung Agung.

Daradjat, Zakiah. 1983. Pendidikan Agama Dalam Pembinaan Mental. Jakarta: Bulan Bintang.

Hamdan. 2003. Riuh di Beranda Satu: Peta Kerukunan Umat Beragama di Indonesia. Jakarta: DEPAG RI.

Hanafi, Mukhlis M. 2013. Moderasi Islam. Ciputat: Ikatan Alumni Al-Azhar dan Pusat Studi AlQur'an (PSQ).

Hawari, Dadang. 1996. Al-Qur'an Ilmu Kedokteran dan Kesehatan Jiwa, (Yogyakarta : Dana Bkahti Prima Yasa.

Henslin, James M. 1990. Social Problems, Prentice Hall. Edisi II. New Jersey: Englewood.

Jalaluddin. 2015. Psikologi Agama. Jakarta: PT Raja Grafinda.

Jusmiana, A. (2020). Sekapur Sirih Tentang Statistik.

Kamali,Mohammad Hashim. 2015. The Middle Path of Moderationin Islam - The Qur'anic Principle of Wasatiyyah. Edisi I. London: Oxford University Press. 
Kementerian Pendidikan dan Kebudayaan RI.2014. Kamus Besar Bahasa Indonesia Pusat Bahasa.Jakarta: PT Gramedia Pustaka Utama.

Launa. 2000. Gerakan Intelektual Dan Aksi Massa Mahasiswa: Refleksi dan Prospeksi Peran Politik Mahasiswa Era Orde Bar. Jurnal Widya.Edisi 183.

Leny dan P. Tommy Y. Suyasa.2006. Keaktifan Berorganisasi dan Kompetensi Interpersonal. Jurnal Phronesis Vol. 8.No.1.Juni 2006.Bandung: Universitas Tarumanegara.

Muqoyyidin, Andik Wahyun. 2013. Membangun Kesadaran Inklusif Multikultural untuk Deradikalisasi Pendidikan Islam.Jurnal Pendidikan Islam.Vol. 2.No. 1 Tahun 2013.

Nurrohim, Ahmad. 2016. Mental Dan Pendidikan Karakter: Pandangan Keislaman Terintegrasi.Vol.I, No. 2, Desember 2016.

Priyatno, Duwi. 2012. Cara Kilat Belajar Analisis Data dengan SPSS 20. Yogyakarta: Andi Offset.

Ramayulis. 2002. Psikologi Agama. Jakarta: Kalam Mulia.

Republik Indonesia. Undang-undang No. 20 Tahun 2003 tentang Sistem Pendidikan Nasional, Pasal 1, ayat (2).

Rifai, Afif.2003. Konflik Etno Religius Indonesia Kontemporer, Jakarta: DEPAG RI.

Rohimah, Rt. Bai. 2019. Persepsi Santri tentang Moderasi Islam dan Wawasan Kebangsaan, Jurnal Hayula.Vol. 3.No. 2. Serang: FKIP UNTISTA.

Sahetapy, J.E. 1981. Kausa Kejahatan dan Beberapa Analisa Kriminologik, Bandung: Penerbit Alumni.

Slameto. 2003. Belajar dan Faktor-faktor yang Mempengaruhinya. Jakarta: Rineka Cipta.

Sudjana, Nana. 2009. Penilaian Hasil Proses Belajar Mengajar.Bandung : PT. Remaja Rosdakarya.

Sugiyono, 2012.Metode Penelitian Kuantitatif Kualitatif dan R\&D. Bandung: Alfabeta.

Sunyoto, Danang. 2013. Teori, Kuesioner, dan Analisis Data Sumber Daya Manusia dalam Organisasi Sekolah. Yogyakarta:Multi Presindo.

Suroto. 2016. Dinamika Kegiatan Organisasi Kemahasiswaan Berbasis Kearifan Lokal Dalam Upaya Memperkuat Karakter Unggul Generasi Muda.Jurnal Pendidikan KewarganegaraanVol. 6.No. 2. Banjarmasin: Universitas Lambung Mangkurat.

Sururi. 2004. Ilmu Jiwa Agama. Jakarta:PT Raja Grafindo Persada.

Suryabrata, Sumadi. 2014. Psikologi Pendidikan. Jakarta: Rajagrafindo Persada. 
Syahid, Ahmad. 2003. Riuh di Beranda Satu:Peta Kerukunan Umat Beragama di Indonesia. Jakarta: DEPAG RI.

Tim Penyusun. 2019. Moderasi Beragama. Cet. I. Jakarta: Kementerian Agama RI.

Wahyudin, Agus. 2015. Metodologi Penelitian Bisnis Dan Manajemen. Semarang: Fakultas Ekonomi Universitas Negeri Semarang.

Winarsih, Atik Septi dan Ratminto. 2012. Manajemen Pelayanan. Yogyakarta: Pustaka Pelajar.

Yusuf, Syamsu. 2004. Mental Hygiene Pengembanagan Kesehatan Mental dalam Kajian Psikologi dan Agama. Bandung: Pustaka Bani Quraisy.

\section{Internet:}

"Bedah Buku Karya Haidar Bagir di IAIN Surakarta Berlangsung Lancar" dalam http://regional.kompas.com/read/2017/05/09/12053501/bedah.buku.di.iain.surakarta. dijaga.1.000.polisi.dan.tni (diakses pada 15 November 2019).

BNPT: Hati-Hati Radikalismedi Kalangan Mahasiswa Capai Angka 20,3\%" dalamhttp://diktis.kemenag.go.id/index.php?berita=detil\&jd=162 (Diakses pada 1 November 2019)

Kepala BNPT: Mahasiswa Baru Jadi Incaran Radikalisme dalamhttps://tekno.tempo.co/read/1241844/kepala-bnpt-mahasiswa-baru-jadiincaranradikalisme (Diakses 15 November 2019) 